\title{
Pottery from the Volga area in the Samara and South Urals region from Eneolithic to Early Bronze Age
}

\author{
Nina L. Morgunova \\ Orenburg State Pedagodical University, RU \\ nina-morgunova@yandex.ru
}

\begin{abstract}
The paper presents the evolution of pottery from the early Eneolithic period to the Early Bronze Age in the Volga area in the Samara and South Urals in accordance with typological and technological characteristics of pottery from the Samara culture and the early stage of the Yamnaya (Pit-Grave) culture. It is established that the Early Bronze Age pottery represent various traditions of both local and migrating populations.

IZVLEČEK - V članku predstavljamo evolucijo lončenine na območju reke Volge v pokrajinah Samare in južno od gorovja Ural, in sicer od zgodnjega eneolitskega obdobja do zgodnje bronaste dobe. Ta razvoj gradimo na tipoloških in tehnoloških značilnostih posod iz kulture Samara in iz zgodnjega obdobja kulture Yamnaya (kultura jaškastih grobov). Za zgodnje bronastodobno lončenino je značilno, da predstavlja različne tradicije tako lokalnih kot priseljenih skupin ljudi.
\end{abstract}

KEY WORDS - Volga area in the Samara and South Urals; Eneolithic; Early Bronze Age; pottery; typological, technological and cultural analysis; radiocarbon dating

\section{Introduction}

One of the most debatable problems in Early Bronze Age archaeology typical to the Volga-Ural steppes centres around the origin of metallurgy and cattle husbandry in the Dnieper-Volga-Ural steppes. These economic achievements of the steppe population are associated with the Yamnaya (Pit-Grave) culture of the Early Bronze Age (Merpert 1974; Ivanova 2001; Morgunova 2014).

The discovery of cultures from the Eneolithic (Copper) period, such as the Samara and Khvalynsk cultures between the Volga and the Urals, is important in archaeology for solving the problem of the origin of Yamnaya culture and the development of metallurgy in this region (Fig. 1). Sites dating to two stages of the Samara culture have been found in the forest-steppe part of the Volga-Ural area along the Samara River (the Samara and Orenburg regions): the early stage, called Sjezheye, and the later stage, called Ivanovo-Toksky. The Samara culture is represented by various sites, including burial grounds and settlements (Vasilyev 1981; Morgunova 1995). Most of the Khvalynsk culture sites have been found in the steppe zone of the Volga area, represented by both large cemeteries and settlements (Vasilyev 1981; 2003).

Srednestog culture sites lie to the west of the Vol$\mathrm{ga}$, in the Don and Dnieper areas (Telegin 1973; Kotova 2006). It has been established that the second stage of the Samara culture was contemporaneous with Khvalynsk and Srednestog cultures. The populations of these three cultures were engaged in settled cattle husbandry (Telegin 1973; Vasilyev 1981; Morgunova 1995; 2014).

The matter in question can also be reduced to the controversy about the role of various Eneolithic groups in the development of Yamnaya culture in the Volga-Ural region. Some researchers believe that it appeared during the Eneolithic period (Merpert 1974 ) in the eastern part of the east European steppes on the basis of the Khvalynsk and Srednestog cultures (Merpert 1974; Telegin 1973; Vasilyev 1981; 
Morgunova, Khokhlova 2013; Morgunova 2014). Therefore, the theory offered by Maria Gimbutas about the massive migration of Yamnaya tribes from east to west as far as the Balkans in the Early Bronze Age has gained greater acceptance (Gimbutas 1979; 1980; Merpert 1965; 1974). Other researchers maintain that the Yamnaya culture community formed over a larger area that included the western Black Sea and Balkan areas (Ivanova 2009; Manzura 2006).

In order to solve this problem, it is of paramount importance to thoroughly study pottery of the Eneolithic period and those of the Yamnaya culture. The ceramics in question have been analysed typologically to determine the shape and proportions of the vessels, their neck and bottom decoration, and special motifs. An important addition to the typological method was the technological study in accordance with the method suggested by Alexander Bobrinsky (1978).

We studied the composition of clays, pottery, types of surface treatments and ornamentation with a binocular microscope (Vasiljeva 1999; Salugina 2005; 2014). The results of the study are important for obtaining historical and cultural evidence to show continuity (or its absence) among Eneolithic steppe cultures and the Yamnaya culture of the Early Bronze
Age. This focus is central in understanding the transfer of technological choices of potters from generation to generation which was most probable related to kinship relations. Pottery studies were assisted by radiocarbon dating, which enabled us to establish the chronology of the Samara, Khvalynsk and Yamnaya cultures (Morgunova et al. 2010; Morgunova 2011; 2014).

\section{Pottery of the Samara culture}

The first stage in the development of the Samara culture is represented by the burials at the village of Sjezheye. The burials exhibit certain rituals, as well as decorations made of shells and the fang of a wild boar, stone axes and other goods (Fig. 2.7-10) that are similar to those found in burials at Mariupol in Ukraine (Makarenko 1933).

Pottery from the Sjezheye burials at can be divided into two types. The first includes high vessels with a small flat bottom (Fig. 2.1-3). The rim-like collars are rather pronounced. The technological study showed that the vessels were made of clay containing silt with an admixture of shell and with some organic solution added to the clay. The vessels were shaped using plastic molds. It has been experimentally established that clays with ground shells were fired in a special way. The surfaces

Fig. 1. Eneolithic settlements (1-5, 7, 10-16, 20, 22-43, $48,50)$, burial grounds (6, 8-9, 17-19, 21, 47, 49) and kurgans (44-46) of the steppe Ural-Volga region: 1 Ivanovka; 2 Turganik; 3 Kuzminki; 4 Mullino; 5 Davlekanovo; 6 Sjezheye (burial ground); 7 Vilovatoe; 8 Ivanovka; 9 Krivoluchye; 10-13 LebjazhinkaI-III-IV-V; 14 Gundorovka; 15-16 Bol. Rakovka I-II; 17-18 Khvalunsk I-II; 19 Lipoviy Ovrag; 20 Alekseevka; 21 Khlopkovskiy; 22 Kuznetsovo I; 23 Ozinki II; 24 Altata; 25 Monakhov I; 26 Oroshaemoe; 27 Rezvoe; 28 Varpholomeevka; 29 Vetelki; 30 Pshenichnoe; 31 Kumuska; 32 Inyasovo; 33 Shapkino VI; 34 Russkoe Truevo I; 35 Tsaritsa I-II; 36 Kamenka I; 37 Kurpezhe-Molla; 38 Is-

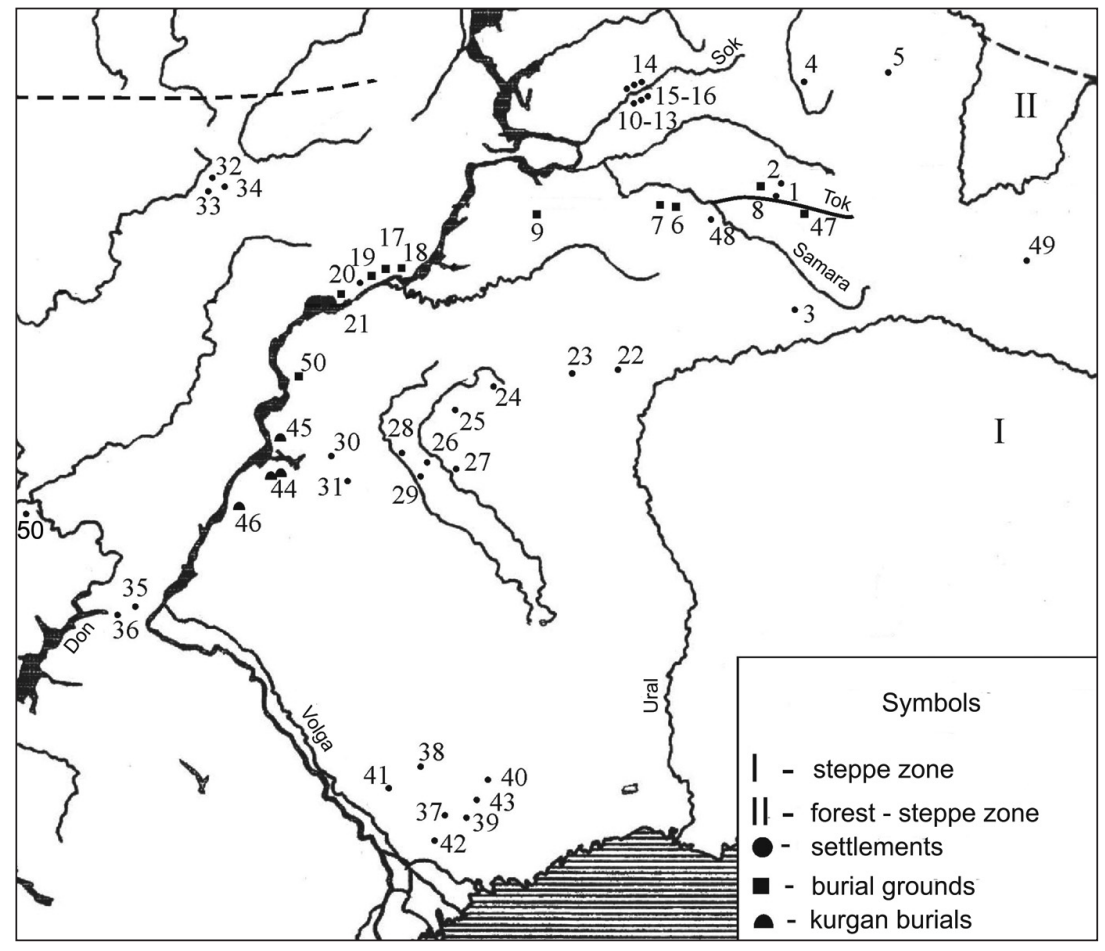
tay; 39 Isekiy; 40 Koshalak; 41 Kara-Khuduk; 42 Kair-Shak VI; 43 Kombakte; 44 Berezhnovka I-II; 45 Rovnoe; 46 Politotdelskoe; 47 burial near s. Pushkino; 48 Elshanka; 49 Novoorsk; 50 Khutor Repin. 
were painted with ochre (Vasilyeva 1999; 2006). The pottery has complex motifs with meander patterns and zigzags, which were made with incisions and comb stamps.

The pottery of the second type differs from the former both typologically and technologically (Fig. 2.4-6). Here, not all the vessels have collars and the necks are prominently made with the help of rows of deep pits and grooves; the bottoms are large and flat. Since they were made from silt produced in water basins, these vessels had a natural admixture of small shells; the material also contains some organic solution (Vasilyeva 1999). The surfaces are covered with motifs made with comb stamps. These distinctive features point to the connection of the second group of pottery to the local Neolithic cultures and their active participation in the development of the Eneolithic Samara culture in the Volga-Ural area (Morgunova 1995; Vasilyeva 2006).

As to the ceramics of the first type,
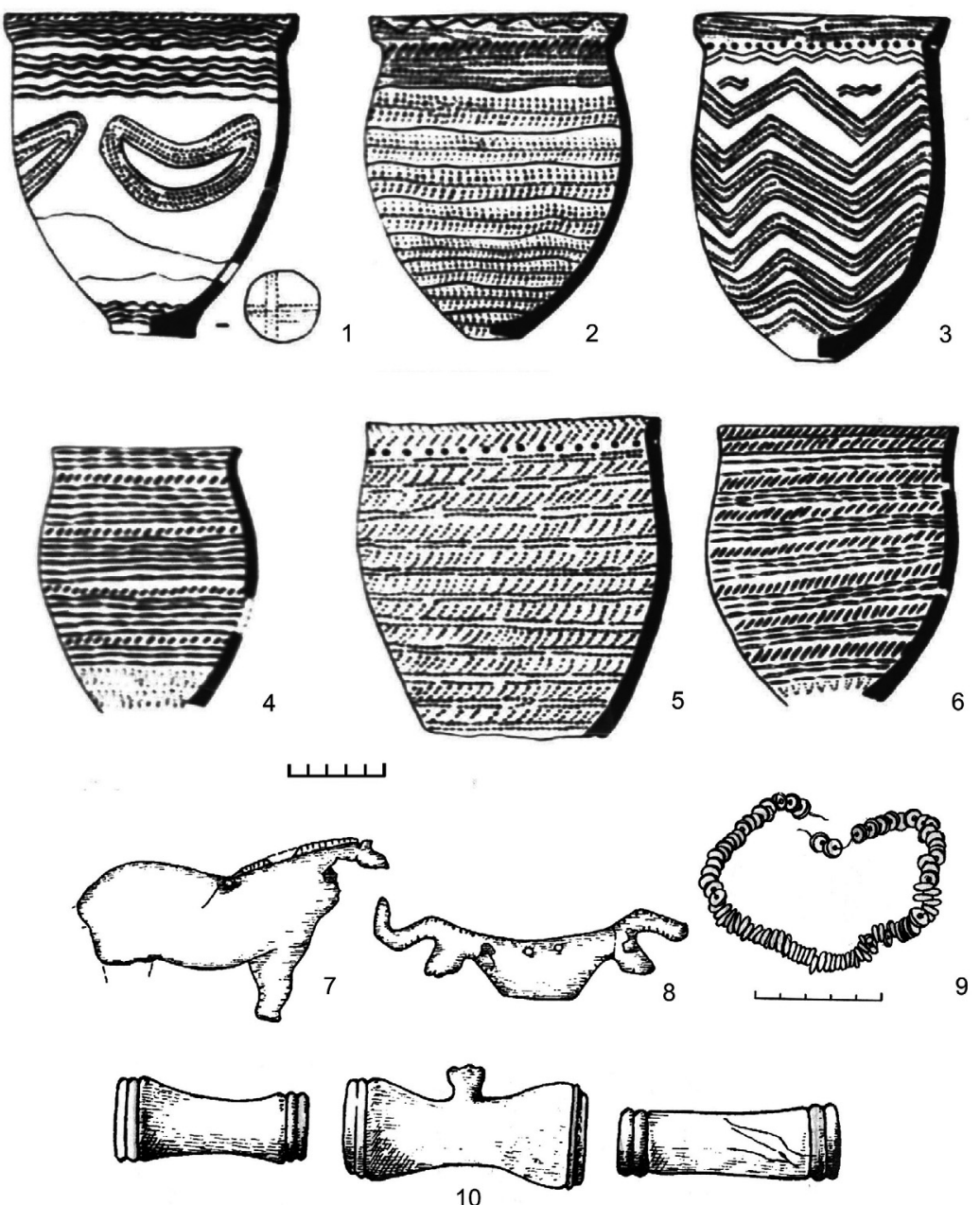

Fig. 2. Materials from the Sjezheye burial ground: 1-3 pottery I group; 4-6 pottery II group; 7-8 bone amulets; 9 shell beads; 10 ornament from wild boar fang. they are supposed to indicate that people of some outlandish culture had entered the areas near the Volga and the Urals. As bearers of different cultural traditions, as evidenced by the pottery excavated at Sjezheye burial ground, the outlandish group appeared to be in a vulnerable position because it was not numerous (Vasilyeva 2006). It had to be assimilated into the local environment by the group that produced the second type of pottery which is found at other sites in the Volga area, such as at the Lebjazhinka III settlement. Consequently, the Samara culture emerged, which marked the onset of the Eneolithic period in the Volga area.

Where did the outlanders who prompted the Eneolithic period in the Volga-Urals region come from? Considering the complex motifs of the pottery in question, which have some prototypes in the AzovDnieper culture and at the early stage of the Tripolsky culture (Kotova 2006), they most probably arrived from the west, i.e. from the north Black Sea area. This is suggested by a certain similarity between the grave goods from burial grounds at Sjezheye and Mariupol (Vasilyev 1981). The presence of close contacts between the population of the Volga area and that of the north-western Black Sea region manifests itself in the similarity in burial practices (large burial grounds, the supine position of the dead, places for sacrifice) and decoration of burial clothing. This evidence testifies to regular links between these groups.

Since this period, one can trace regular ties between the population of the Volga-Urals region and that around the Balkan-Carpathian centre of early metallurgy. During the Eneolithic period, the Volga-Ural population made use of imported metal from the Balkans (Ryndina 1998).

Radiocarbon dates also show that the Sjezheye stage of the Samara culture and the culture of Tripolye A coincided in time. The ceramics and human bones 
from three sites have all been radiocarbon dated to the same period (Morgunova et al. 2010). Their values are shown in Table 1. If we proceed from the majority of dates that coincide, disregarding the most ancient and latest ones, the Samara culture at its Sjezheye stage can be dated from 5300 to $4800 \mathrm{BC}$. This interval appears to be correct, as it corresponds to the dating of the Azov-Dnieper culture and Tripolye Al (Videiko 2004.85-95; Kotova 2002.95-97).

The earlier Sjezheye stage of the $\mathrm{Sa}$ mara culture is also contemporary

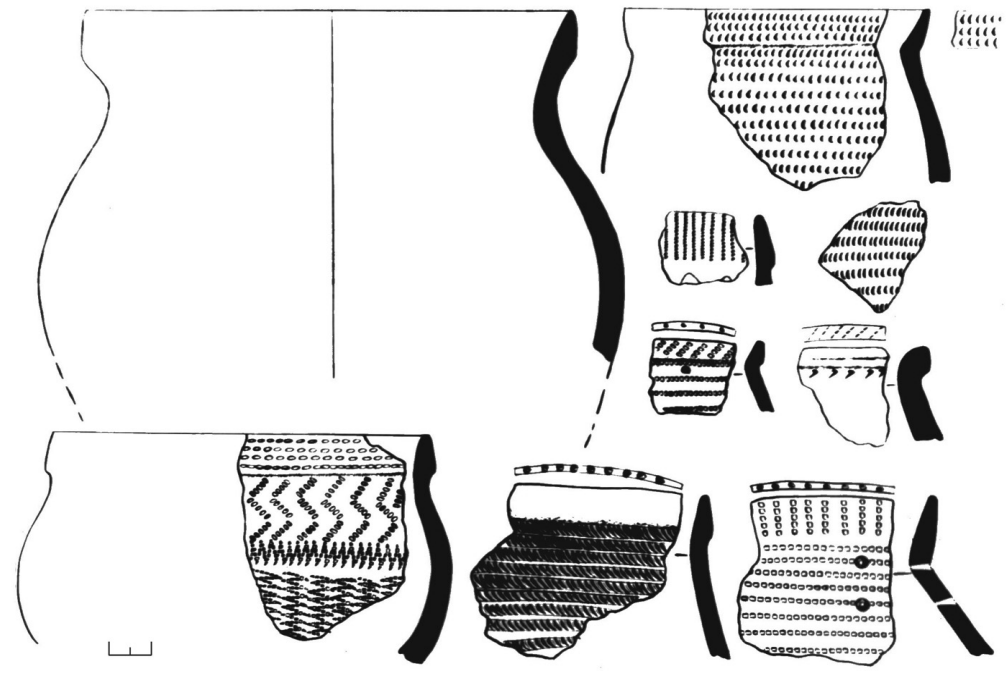

Fig. 3. Ivanovka settlement. Pottery of Ivanovka type.

with the Near Caspian Eneolithic culture in the Low Volga area. Radiocarbon dates of pottery from Varfolomeevka settlement (layer 2A) as well as from other settlements in the North Caspian region show approximately the same interval in the calibrated age (Vybornov et al. 2008).

The second stage in the Samara culture is represented by a number of settlements, among which Ivanovska and Turganic in the Orenburg region are of the greatest interest (Fig. 1). Here we also find two groups of pottery. The first (i.e. Ivanovka type) includes vessels with a collar on the rim (Fig. 3), which continues the pottery tradition typical for the Sjezheye stage. The technological characteristics of Ivanovska pottery confirm this conclusion. Pottery traditions continued from the Sjezheye to the Ivanovska stage in the composition of clays, the shape and proportion of vessels and their ornamentation with comb stamps. But at the same time, the Ivanovska pottery also includes some changes both in the variety and technological features, such as missing grooves under the rim and meander compositions, different shapes of collars etc.
The second group (i.e. Toksky type) of pottery typical to the second stage of the Samara culture includes profiled vessels without collars. It generally has the same technological traditions as the second group of pottery typical to the Samara culture at its Sjezheye stage, but with some changes (Fig. 4).

The changes during the second stage of the Samara culture could be the result of influences from the Khvalynsk culture (Morgunova 2011; Vasilyeva 2006.22). The evidence below testifies to close contacts between the populations of the Khvalynsk and Samara cultures. Pottery of the Khvalynsk type was found in the form of imported items at all sites related to the second stage of the Samara culture. Some grave goods were found which were similar to those found at the Khvalynsk burial ground (such as beads and shell decorations, stone bracelets, etc.). In addition, the technological study showed that the Ivanovka pottery had features typical of the Khvalynsk culture (e.g., clays containing silt, wicker elements in ornamentation, etc.) which is evidence of contacts between these two groups of the Volga population (Morgunova 1995; Vasilyeva 2006).

\begin{tabular}{|lcccc|}
\hline Complex & Index & Material & Age BP & Age BC 68\% \\
\hline Sjezheye (burial ground) & Ki 14525 & pottery & $6760 \pm 80$ & $5730-5610$ \\
\hline Sjezheye (burial ground) & Ki 14526 & pottery & $6580 \pm 100$ & $5630-5470$ \\
\hline Sjezheye (burial ground) & Ki 14527 & pottery & $5890 \pm 90$ & $4860-4670$ \\
\hline Lebjazhinka III (settlement) & Ki15580 & pottery & $6035 \pm 80$ & $5040-4800$ \\
\hline Lebjazhinka III (settlement) & Ki15577 & pottery & $5930 \pm 80$ & $4910-4870$ \\
\hline Lebezhinka III (settlement) & Ki15582 & pottery & $6055 \pm 80$ & $5060-4840$ \\
\hline Lebjazhinka III (settlement) & Ki15578 & pottery & $6140 \pm 80$ & $5210-5160$ \\
\hline Lebjazhinka V (burial ground 9) & Ki 7657 & man bone & $6280 \pm 90$ & $5350-5100$ \\
\hline Lebjazhinka V (burial ground 12) & Ki 7661 & man bone & $6510 \pm 80$ & $5680-5450$ \\
\hline
\end{tabular}

Tab. 1. Radiocarbon dates for the early stage of Samara culture (Sjezheye type).
Thus, we can ascertain the synchronic character of the materials typical to the second stage of the Samara culture and those excavated from the Khvalynsk burial grounds in the Lower Volga area and, therefore, the materials of the Srednestog culture in the nearby Dnieper steppes (Vasilyev 1981). 


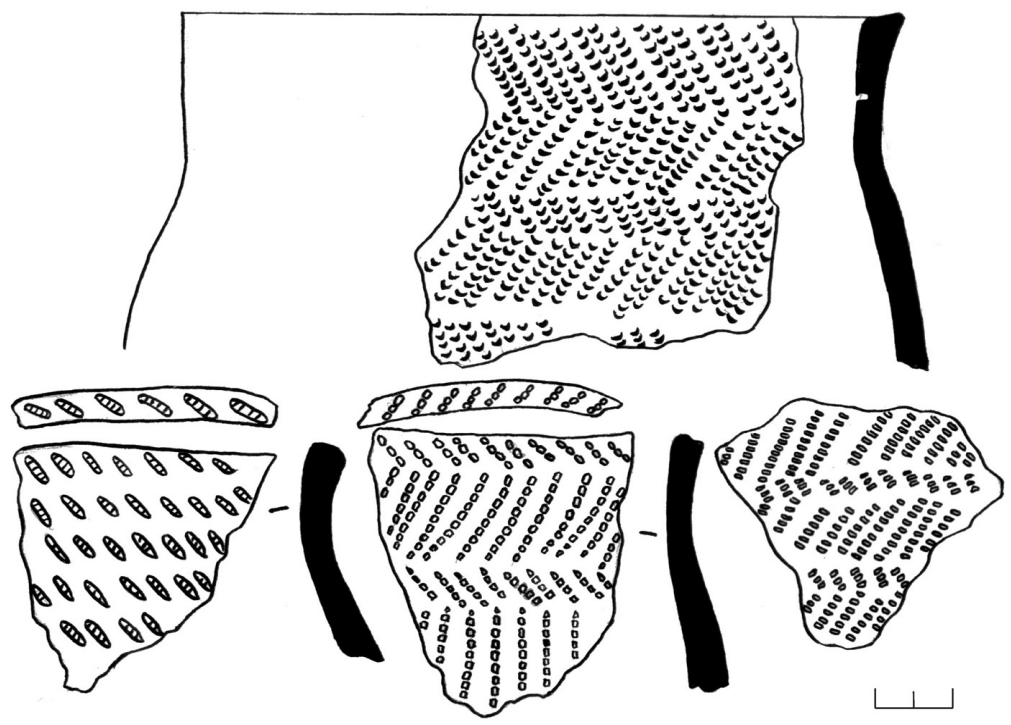

Fig. 4. Ivanovka settlement. Pottery of Toksky type.

The later date of grave goods belonging to the Ivanovka and Toksky type with respect to those characteristic to the Sjezheye stage of the Samara culture is confirmed by radiocarbon dating (Tab. 2). The calibrated period of the Samara culture at its second stage is $4850-3640 \mathrm{BC}$. Chronologically, the Ivanovka type corresponds to the Khvalynsk and Srednestog cultures (Morgunova et al. 2010; Kotova 2006). Considering these dates, the technological tradition characteristic to the Ivanovka type ends around 4300-4400 BC, while the features of the Toksky type pottery continue into the first half of the $4^{\text {th }}$ millennium $\mathrm{BC}$.

\section{Pottery of the Early Bronze Age}

The Turganik pottery type continued the tradition of the Samara culture. This is seen in a number of features in both the shapes of the vessels as in their decorations (Fig. 5). On the whole, the pottery is distinguished by its originality, while the pronounced profiled neck and presence of ground shell in the clay make it possible to date them contemporaneously with artefacts from sites of the Repin stage of the Yamnaya culture and those of Mikhailovka II in the nearby Dnieper area (Morgunova 1995). This is confirmed by radiocarbon dates (Tab. 3); their calibrated age is estimated at 3930-3510 BC. novka and Toksky types).
The Repin artefacts, as many researchers believe, belong to the early stage of the Yamnaya culture in the Bronze Age (Merpert 1974; Vasilyev 1981; Triphonov 1996; Nicolova 2002; Morgunova 2014). Repin types were found both at transitory camps and burial mounds (kurgans) in the nearby Volga and Ural areas. The name comes from grave goods found at the Repin Khutor settlement in the nearby Don area.

The Repin pottery is quite original (Fig. 6). In terms of typological features, they comprise high vessels with profiled necks and spherical or flat bottoms. The technological study showed that the vessels were made with silt or clay containing silt, with an admixture of ground shells and some organic solutions. The surface of the vessels was smoothed and then decorated with comb stamps in different motifs. The vessels were formed with the help of molds (Salugina 2005).

They combine the characteristic features of all the Eneolithic pottery that was present in this area as well as some elements characteristic to the Khvalynsk and, especially, Srednestog cultures. The study of the Repin pottery shows continuity in the methods of pottery technology and morphology practiced by other Eneolithic steppe cultures of the Volga-Ural and Near Don areas. It indicates the process of active blending and integration that took place among the steppe people at that time and resulted in the Yamnaya culture spreading over a vast area.

\begin{tabular}{|c|c|c|c|c|}
\hline Complex & Index & Material & Age BP & Age BC $68 \%$ \\
\hline Kuzminki settlement & Ki 15066 & pottery I type & $5630 \pm 70$ & $4540-4360$ \\
\hline Turganik settlement & Ki 15067 & pottery I type & $5660 \pm 70$ & $4590-4440$ \\
\hline Turganik settlement & Ki 14516 & pottery I type & $5790 \pm 90$ & $4730-4530$ \\
\hline Gundorovka settlement & Ki 14523 & pottery I type & $5840 \pm 80$ & $4790-4590$ \\
\hline Ivanovka settlement & LE 8413 & animal bone & $5870 \pm 130$ & $4851-4550$ \\
\hline Turganik settlement & Ki 14517 & pottery II type & $5830 \pm 70$ & $4780-4590$ \\
\hline Ivanovka settlement & Ki 15068 & pottery II type & $4930 \pm 80$ & $3800-3640$ \\
\hline Ivanovka settlement & $\mathrm{Ki} 15070$ & pottery II type & $5070 \pm 80$ & $3960-3780$ \\
\hline Ivanovka settlement & Ki 15089 & pottery II type & $4940 \pm 80$ & $3800-3640$ \\
\hline Lebjazhinka IV settlement & Ki15583 & pottery II type & $5420 \pm 70$ & $4350-4220$ \\
\hline $\begin{array}{l}\text { Gundorovka settlement, } \\
\text { burial 10, type II of pottery }\end{array}$ & GIN 9041 & man bone & $5120 \pm 140$ & $4080-3720$ \\
\hline $\begin{array}{l}\text { Gundorovka settlement, } \\
\text { burial } 11 \text {, type II of pottery }\end{array}$ & GIN & man bone & $5130 \pm 50$ & 3982 \\
\hline
\end{tabular}

Tab. 2. Radiocarbon dates for the second stage of Samara culture (Iva- 
During that period, the life of the entire Volga-Ural population underwent fundamental changes. A completely novel method of cattle breeding appeared in addition to the changes in pottery technology (Merpert 1974; Morgunova 2014). Settlements in the Repin period were few and short-lived, while the ritual of burying under kurgans became more widespread. This means that cattle breeding gradually acquired a nomadic character. The materials from the Yamnaya culture show all the signs of nomadic cattle breeding: natural climatic conditions and the scope for adaptation to them; the character of herds (sheep, horse, cat-

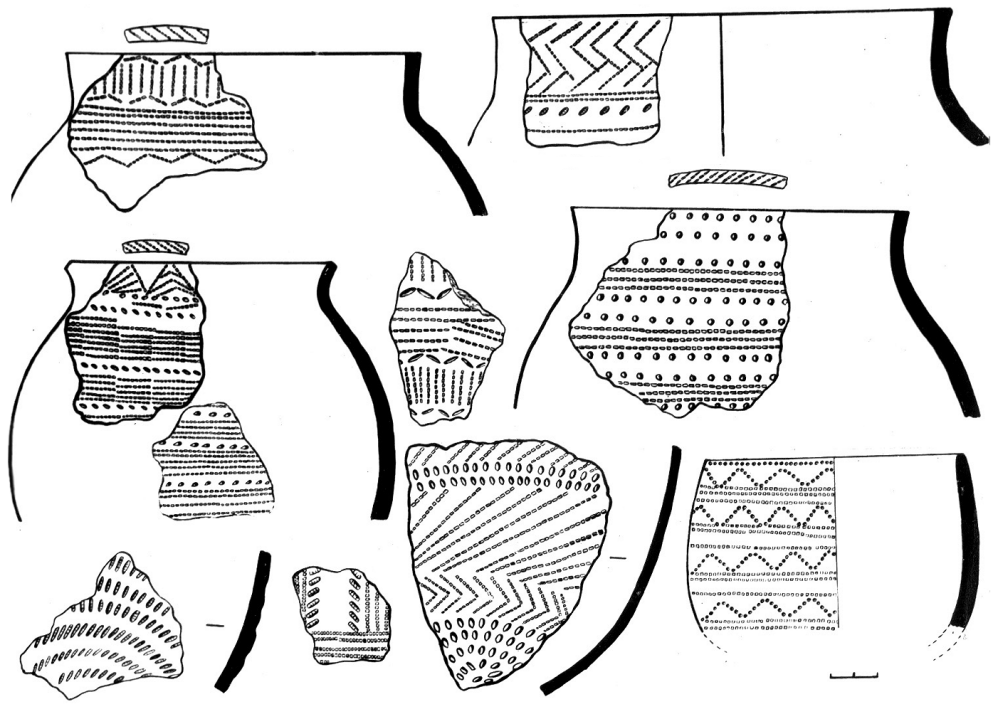

Fig. 5. Ivanovka settlement. Pottery of Turganik type.

tle); technological means: the character of homes and means of wheeled transport, effective household utensils and implements (Morgunova 2014).

But especially important in the progressive development of the regional economy was the establishment of its own metal-working centre on the basis of the Kargala copper mines in the Ural area (the Orenburg region). A number of Repin sites yielded metal artefacts produced at this centre (Fig. 6). By this stage, Balkan metal was no longer used in the region in question, which nevertheless retained some of Balkan technologies in the local production of metal items (Degtyareva 2010).

\section{Conclusion}

The study of the Eneolithic and Early Bronze Age ceramics in the Volga and the Urals areas is of great importance. The typological and technological analysis of pottery found at a number of sites related to the Samara and Khvalynsk cultures, on the one hand, and the early (Repin) stage of the Yamnaya culture, on the other, made it possible to show continuity in the production of pottery from the Eneolithic period to the Early Bronze Age, which means that an autochthonous line of development prevailed in the region. The studies were supported by radiocarbon dates.

According to the evidence from the early stage of the Eneolithic Samara culture, we can identify two typological groups of pottery, because the difference between them is confirmed tech- nologically. One of them predominates and finds its origin in the traditions of the local Neolithic culture. The other group is considered outlandish, connected with the Azov-Dnieper and Tripolsky cultures from the northern Black Sea region.

The outlandish settlers, who were not as numerous, must have been assimilated, but they added originality to the Samara culture and gave rise to the Eneolithic period in the Volga-Ural area. Thereafter, regular economic ties with the northern Black Sea and Balkan region developed, supplying ready-made copper products throughout the Eneolithic period.

The later stage of the Samara culture is also characterised by two types of pottery, both of which continue the traditions of the earlier period. Some of the novel features of the Ivanovka and Toksky pottery resulted from the close contacts of the foreststeppe population with the Khvalynsk and Srednestog cultures of the steppes, which was caused by greater mobility and integral processes in the southern part of east Europe at that time.

In its early period, the Yamnaya culture of the Early Bronze Age is represented by transitory settlements and burial mounds of the Repin type. Their pottery is a combination of vessels characteristic to the late 

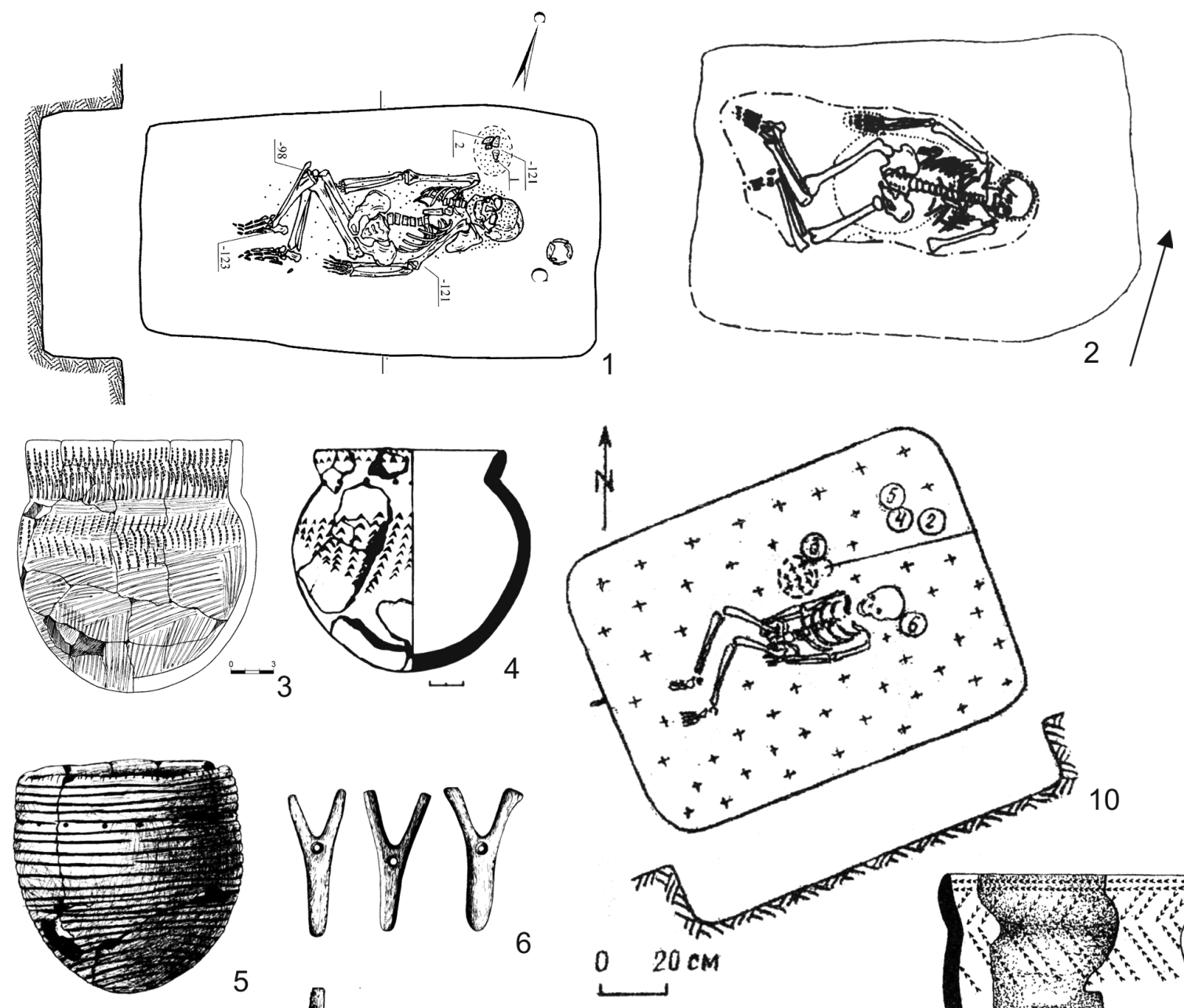

6
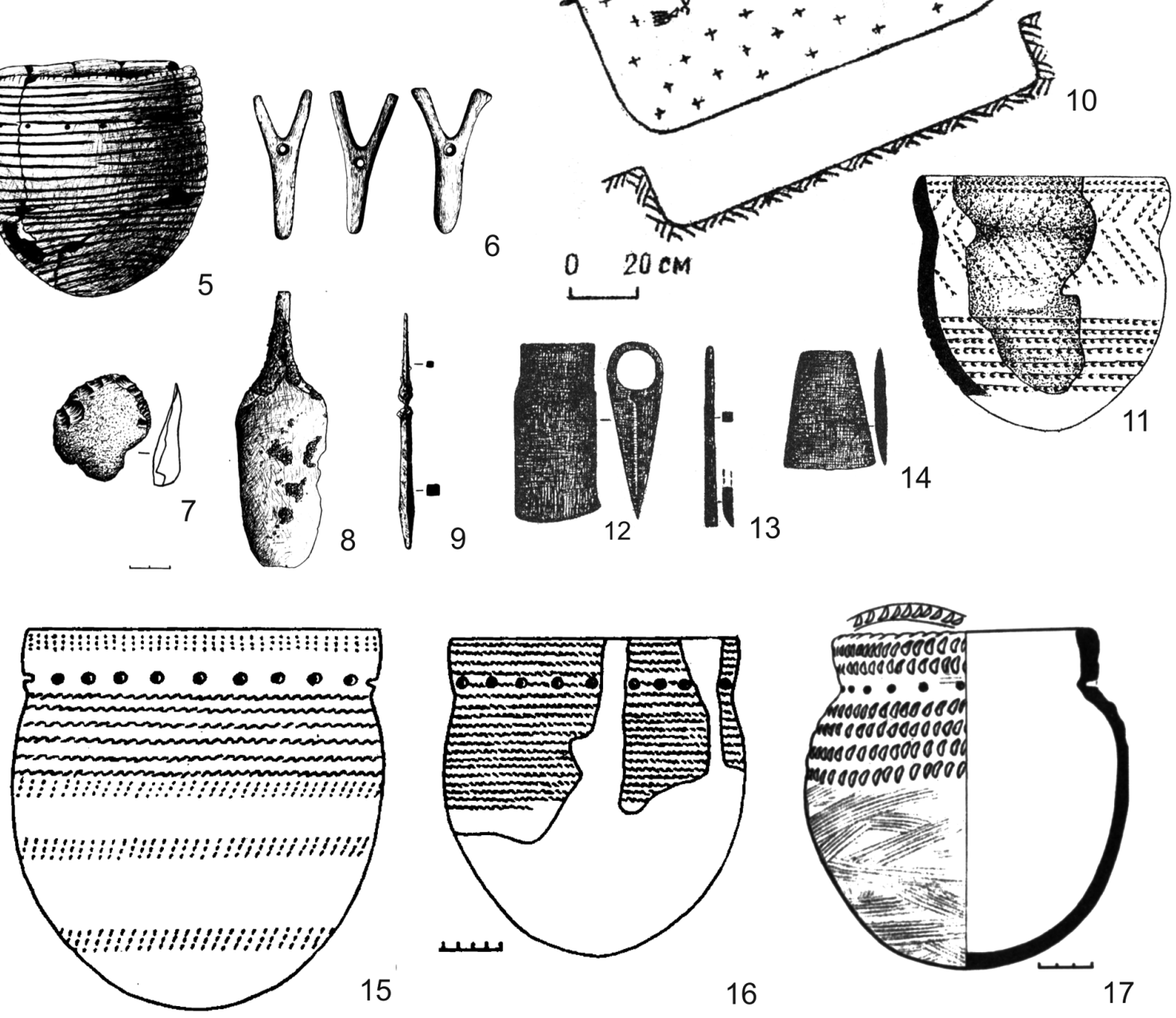

Fig. 6. Materials of the Repin type: 1, 2, 10 burials under kurgans; 3-5, 11, 15-17 pottery; 6 bone; 7 stone; 8-9, 12-14 copper. 
period of the Samara and Khvalynsk cultures. At the same time, the pottery typology reflects some of the features typical to the Srednestog culture, which proves the active role played by all Eneolithic cultures from the Ural to the Dnieper in the development of the Yamnaya culture. Side by side with the predominant Yamnaya culture population, the forest-steppe areas continued to be populated by Eneolithic groups, as represented by pottery of the Turganik type.

Thus, the comprehensive study of pottery based on radiocarbon dates over two periods - the Eneolithic and the Early Bronze Age made it possible to define the periods and chronology of the cultures of the time more exactly. Moreover, it allowed us to trace the continuity and role

\begin{tabular}{|c|c|c|c|c|}
\hline Complex & Index & Material & Age BP & Age BC $68 \%$ \\
\hline Kyzyl-Khak II settlement & Ki 15075 & pottery & $4730 \pm 70$ & $3540-3490$ \\
\hline Kyzyl-Khak I settlement & Ki 14542 & pottery & $4510 \pm 80$ & $3350-3100$ \\
\hline Turganik settlement & Ki 15597 & pottery & $4710 \pm 80$ & $3630-3370$ \\
\hline Turganik settlement & $\mathrm{SPb} 1493$ & animal bone & $4900 \pm 80$ & $3786-3635$ \\
\hline Turganik settlement & $\mathrm{SPb} 1490$ & animal bone & $4887 \pm 80$ & $3786-3631$ \\
\hline Khutor Repin settlement & $\mathrm{Ki} 16486$ & pottery & $4830 \pm 80$ & $3710-3520$ \\
\hline Khutor Repin settlement & Ki 16542 & pottery & $4640 \pm 70$ & $3600-3300$ \\
\hline Khutor Repin settlement & Ki 16541 & pottery & $4630 \pm 80$ & $3600-3300$ \\
\hline Lopatino I, Kurgan 31, b.1 & $\mathrm{Ki} 7764$ & man bone & $4560 \pm 80$ & $3300-3100$ \\
\hline Lopatino I, Kurgan 31, b.1 & Ki 14544 & pottery & $4750 \pm 70$ & $3700-3300$ \\
\hline Lopatino I, Kurgan 31, b.1 & Ki 14545 & pottery & $4800 \pm 80$ & $3700-3300$ \\
\hline Petrovka, Kurgan 1, b.1 & Ki 14521 & pottery & $4730 \pm 90$ & $3640-3490$ \\
\hline Orlovka I, Kurgan 2, b.2 & LE 7896 & man bone & $4790 \pm 150$ & $3700-3400$ \\
\hline Skvortsovka Kurgan 5, b.2 & Ki 16268 & pottery & $5140 \pm 70$ & $4000-3800$ \\
\hline $\begin{array}{l}\text { Skatovka, Kurgan 5, b.3, } \\
\text { vessel } 2\end{array}$ & Ki 16487 & pottery & $4890 \pm 70$ & $3770-363$ \\
\hline $\begin{array}{l}\text { Skatovka, Kurgan 5, b.3, } \\
\text { vessel } 3\end{array}$ & Ki 16488 & pottery & $5080 \pm 80$ & $3970-$ \\
\hline
\end{tabular}

Tab. 4. Radiocarbon dates for Repin sites.

of interactions, ties and migration in the cultural and economic development of the population in the Volga-Urals steppe-forest and steppe zone from the Late Neolithic up to the Early Bronze Age.

The author thanks Prof. M. Budja for his invitation to publish this paper in Documenta Praehistorica, RFH for support with grant No. 14-01-00127 and Ministry of Education Russian Federation for help with the State Assignment No. 33.1471.2014K.

\section{References}

Bobrinsky A. 1978. Pottery of East Europe. Moskow. (in Russian)

Degtyareva A. 2010. The History of metal-working in the South Ural area in the Bronze Age. Novosibirsk. (in Russian)

Gimbutas M. 1979. The Three Waves of the Steppe People into East Europe. Archives Suisses d'Anthropologie Generale 43(2): 113-137.

1980. The Kurgan Wave No. 2 into Europe and the Following Transformation of Culture. Journal of Indo-European Studies 8: 273-317.

Ivanova S. 2001. The social structure of the Pit-Grave culture in North-West Pre- Black Sea. Odessa. (in Russian)
2009. Historical situation in South-East Europe (Eneolithic period - Early Bronze Age). In Problems of studying steppes cultures of Early Bronze Age in East Europe. Orenburg: 49-58.

Kotova N. 2002. The onset of the Neolithic period in Ukraine. Kiev. (in Russian)

2006. Early Eneolithic period in the steppes of the Dnieper and Azov region. Lugansk. (in Russian)

Makarenko N. 1933. Mariupol cemetery. Kiev. (in Ukrainian)

Manzura I. 2006. Burial ritual of the Eneolithic period in South Russia steppes in the foreshortened Europian parallels. In Yamnaya cultural and historical area: Problems of study. Orenburg: 60-62. (in Russian). 
Merpert N. 1965. On the connection between the North Black Sea area and the Balkans in the Early Bronze Age. Short reports of the Institute of archeology of the USSR 105: 10-20.

1974. Ancient cattle-breeders in the Volga-Ural area. Moscow. (in Russian)

Morgunova N. 1995. Neolithic and Eneolithic periods in the south forest-steppes of the Volga-Ural area. Orenburg. (in Russian)

2011. Eneolithic period in the Volga-Ural area. Orenburg. (in Russian)

2014. Ural group of sites in the system of the VolgaUral variant of the Yamnaya cultural and historical area. Orenburg. (in Russian)

Morgunova N., Vybornov A., Kovalukh N. and Skripkin V. 2010. Chronological relation of Eneolithic cultures in the Volga-Ural region in the light of radiocarbon dating. Russian archeology 4: 19-28. (in Russian)

Morgunova N., Khokhlova 0. 2013. Chronology and Periods of the Pit-Grave Culture in the Area between the Volga and Ural Rivers Based on ${ }^{14} \mathrm{C}$ Dating and Paleopedological Research. Radiocarbon 55(2-3): 1286-1296. (in Russian)

Nicolova A. 2002. The place of the Repin culture in the Yamnaya cultural and historical area. In Same questions of the historiography. Problems of the archeology Dnieper area. Dnepropetrovsk: 37-59. (in Russian)

Ryndina N. 1998. Ancient metal-working in Southeast Europe. Moscow.

Salugina N. 2005. Technology of ceramics related to the Repin type from the Yamnaya culture burials in the Volga-Ural area. Russian archeology 3: 85-92. (in Russian)
2014. Ceramics of the Repin type from settlements and burials of the Volga and Pre-Ural area. Archaeological sites of the Orenburg region 14: 60-69.

Telegin D. 1973. Srednestog culture of the Copper period. Kiev. (in Ukrainian)

Triphonov V. 1996. Repin culture and formation of the Yamnaya cultural and historical area. In Antiquity of the Volgo-Don steppe in the system Europian Bronze Age. Volgograd: 3-5.

Vasilyev I. 1981. Eneolithic period in the Volga region. Steppe and forest-steppe. Kuybychev. (in Russian)

2003. Khvalynsk Eneolithic culture of the Volga-Ural steppe and forest-steppe. The questions of the archeology Volga area 3. Samara: 61-99. (in Russian)

Vasilyeva I. 1999. Ceramic technology from the burial ground at Sjezheye settlement. Archaeological sites of the Orenburg region 3: 191-216. (in Russian)

2006. Pottery of the Eneolithic population in the VolgaUral area as a historical source of the Yamnaya culture. In Yamnaya cultural and historical area: Problems of study. Orenburg: 17-23. (in Russian).

Vybornov A., Kovalukh N. and Skripkin V. 2008. On the correction of absolute chronology as regards the Neolithic and Eneolithic periods in the northern Near Caspian area. In Tansactions of All-Russia Archaeological Congress in Suzdal'. Moskow: 191-193. (in Russian).

Videyko M. 2004. The absolute chronology of the Tripolsky culture. Encyclopedia of the Tripolsky civilization 1. Kiev. (in Ukrainian) 
